\title{
La realtà virtuale per il racconto dell'Archeologia. Bedriacum 3D: il disegno per la narrazione di un vicus interrato
}

\author{
Francesca Galasso
}

Abstract

Con l'avvento delle nuove applicazioni di Realtà Virtuale e Realtà Aumentata la comunicazione dei dati inerenti agli scavi archeologici ha subito uno sviluppo nella creazione di banche dati fruibili non più come semplici sistemi informativi, ma come veri e propri contenitori di immagini e rappresentazioni tridimensionali. I modelli 3D, resi interattivi, consentono di sviluppare nuove strategie di comunicazione, narrazione e divulgazione del bene archeologico. La Virtual Archaeology, seguendo linee metodologiche di rappresentazione che prevedono l'utilizzo di modelli tridimensionali interattivi, permette di comprendere non solo lo sviluppo e le fasi di uno scavo archeologico, ma anche di simulare ricostruzioni tridimensionali di un ambiente e in una riconfigurazione diversa da quella attuale. Partendo da un'accurata analisi storica degli elementi e delle strutture dello scavo, è possibile generare un "modello di conoscenza" visuale, popolato di informazioni e contenuti multimediali che permettono di approfondire e raccontare contesti archeologici non accessibili.

La creazione di ambienti virtuali 3D finalizzati non solo alla divulgazione e all'educazione, ma anche all'analisi e alla comprensione del sito archeologico, è uno degli obiettivi della ricerca condotta dal Laboratorio Sperimentale di Didattica e RICERCA DAda-LAB dell'Università degli Studi di Pavia sul sito di Bedriacum, vicus romano nei pressi di Calvatone, in provincia di Cremona. Gli scavi ventennali, effettuati dagli archeologi dell'Università Statale di Milano, hanno portato alla luce i resti di un sistema urbano composto da ville e strutture riferibili a un periodo compreso tra il II sec. a.C. e il V sec. d.C.

Parole chiave

Virtual Archeology, modelli tridimensionali, Realtà Virtuale, rappresentazione digitale, Bedriacum.

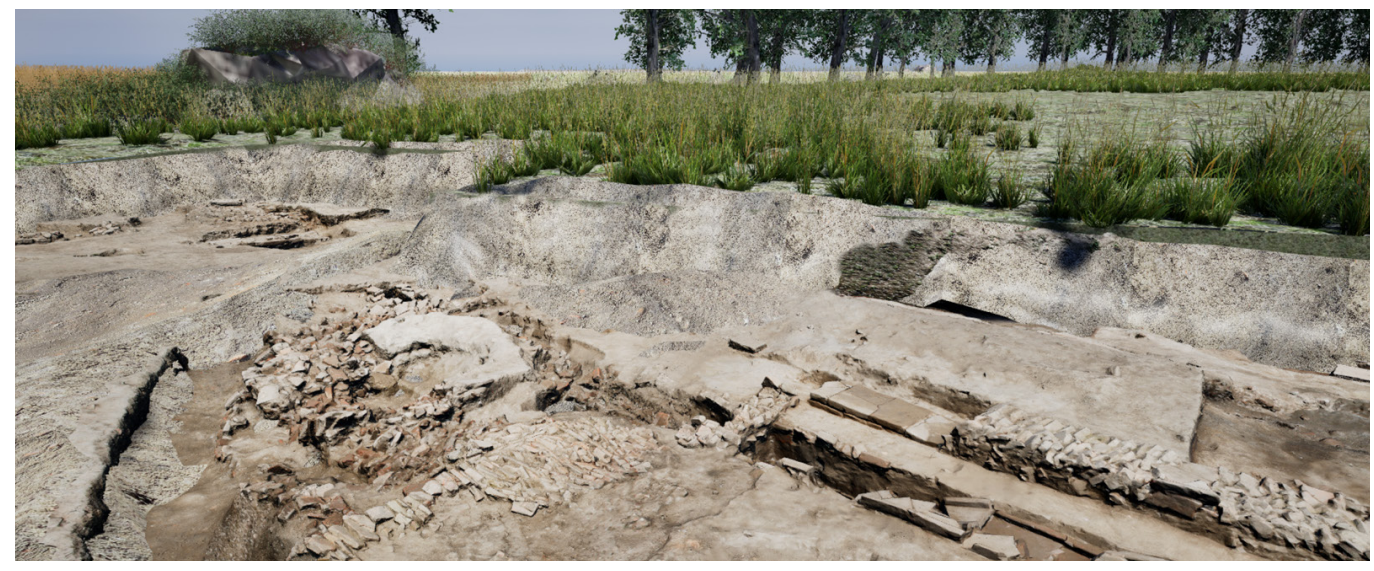




\section{Comunicare la storia nell'era digitale: Virtual Heritage e Virtual Archaeology}

La moltiplicazione delle identità, degli individui così come dei beni culturali, che negli ultimi anni dell'era digitale ha rivoluzionato l'interazione sociale e culturale, offre numerosi spunti di riflessione per contestualizzare e ripensare il ruolo dei modelli per la valorizzazione di contesti culturali e, più in generale, per definire strumenti alternativi di fruizione della conoscenza.

La digitalizzazione del patrimonio culturale ha permesso di creare database interrogabili e metricamente affidabili per consentire ai diversi operatori coinvolti nei processi di documentazione di rispondere alle esigenze e alle problematiche di gestione del patrimonio culturale. Questa eredità digitale rappresenta il principale punto di partenza nella divulgazione delle complesse ed eterogenee informazioni riguardanti i beni culturali.

Applicazioni di Realtà Virtuale nell'ambito del Cultural Heritage descrivono un'offerta informativa che cerca di servirsi del 'virtuale' come mezzo per la valorizzazione del reale. Attraverso l'amplificazione delle specificità di un determinato fenomeno, la costruzione di sistemi multimediali consente una fruizione più dettagliata e più personale dei contenuti museali. La possibilità di interconnettere dati in uno spazio dislocato nella rete consente di creare connessioni per sviluppare percorsi attrattivi di un determinato contesto da parte di una specifica utenza.

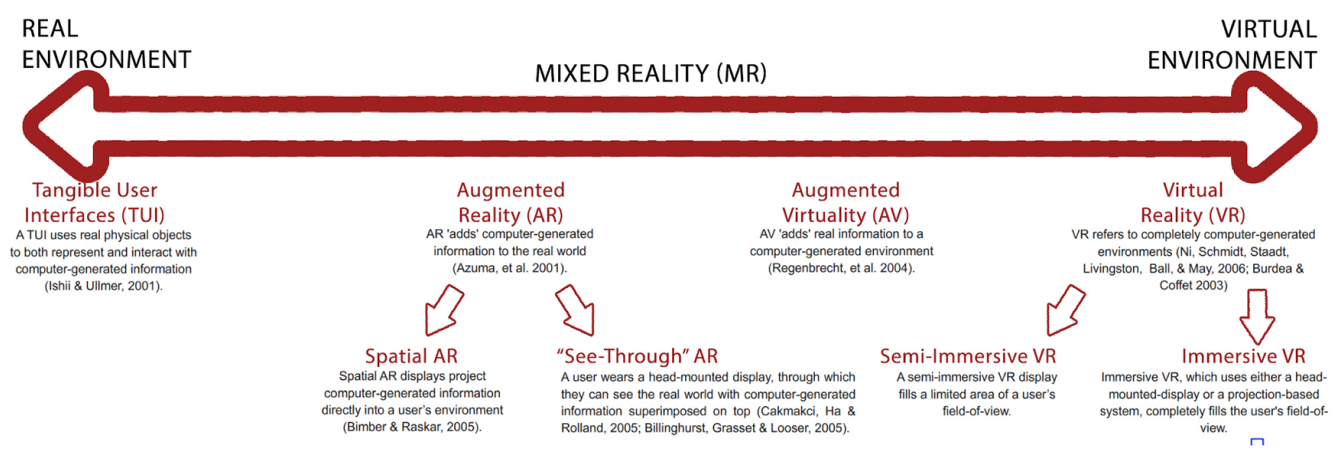

Discipline come la storia, l'architettura e l'archeologia sperimentano l'utilizzo di tecnologie di Realtà Virtuale, Realtà Aumentata e Realtà Mista [ I] per la valorizzazione delle opere principalmente secondo due metodologie differenti: da un lato collocando oggetti tridimensionali virtuali in contesti reali, integrando informazioni di diversa tipologia, dall'altro ricostruendo ambientazioni verosimili fruibili attraverso sistemi Head Mounted Display (HMD). II ricorso alle tecniche di simulazione, tecnologie immersive e ricostruzioni tridimensionali interrogabili risponde ad uno degli obiettivi fondamentali del Virtual Heritage: "to convey not just the appearance but also the meaning and significance of cultural artefacts and the associated social agency that designed and used them" [Champion 2008 pp. 185-206]

Attualmente, anche nel campo dell'archeologia, si riscontra un uso sempre più assiduo delle tecnologie informatiche: dalle investigazioni sul campo, alla raccolta dei dati, fino alla ricostruzione storica degli eventi e delle fasi di sviluppo di una data cultura perduta. In questo senso, il Virtual Heritage si traduce in quello che Paul Reilly ha definito Virtual Archaeology [2]. La ricostruzione virtuale del patrimonio archeologico è uno degli strumenti più innovativi per conservare e custodire la memoria storica dei luoghi, ponendo in relazione le tracce appartenenti alle epoche passate. La possibilità di osservare ciò che non è più permette di trasformare "from imaginary to existing in our understanding" [Yu Hookk 20 I 6, p. 647] potendo così mettere in contatto la memoria con chi fruisce un determinato spazio.

Tale processo implica che i modelli si configurino come il risultato di un'attività di codifica dei segni materiali presenti sul luogo e delle informazioni reperibili nei documenti storici o archivistici. 
Fig. 2. Inquadramento storico del vicus romano di Bedriacum. Dalla cartografia storica si delinea (1) postumia con parti(a) colare attenzione alla sua presenza in prossimità del fiume Oglio.
In questo modo nel modello digitale il tempo si ferma e si moltiplica, favorendo quella configurazione museale per cui i siti e i musei archeologici "sono considerati luoghi in cui si preserva nel tempo [...] la memoria storica e artistica [...] contribuendo alla divulgazione del sapere e della cultura" [Ragni 2008, pp. 2-26].

Le minacce che incombono su uno spazio digitale, in termini di compromissione della sua possibilità di perdurare nel tempo, sono diverse da quelle di uno spazio reale. Le modalità di duplicazione e dislocamento di una banca dati in numerosi archivi fa sì che oggi probabilmente lo spazio digitale sia in qualche modo più sicuro e le informazioni contenute in un archivio, sia questo un modello informativo o una piattaforma di connessione dati, possono essere visitate e messe in relazione con molti più utenti di quanto non possa accadere per un luogo reale, vincolato tra le tante, alla propria collocazione in uno specifico luogo.

Per questo motivo, l'archeologia virtuale si presenta come il risultato dell'applicazione di differenti ricerche/progetti all'interno di studi interdisciplinari dove la Realtà Virtuale si propone non solo come lente di ingrandimento per l'analisi e lo studio delle strutture di scavo o dei manufatti portati alla luce, ma anche come "portale visuale" [Guidazzoli, Liguori 20 I I, pp. 2-26] del passato in cui, attraverso ricostruzioni tridimensionali di ambientazioni antiche, derivanti da ipotesi e analisi storiche, i ricercatori e i fruitori possono ottenere differenti tipologie di informazioni, a differenti scale di dettaglio in base alle impostazioni selezionate.

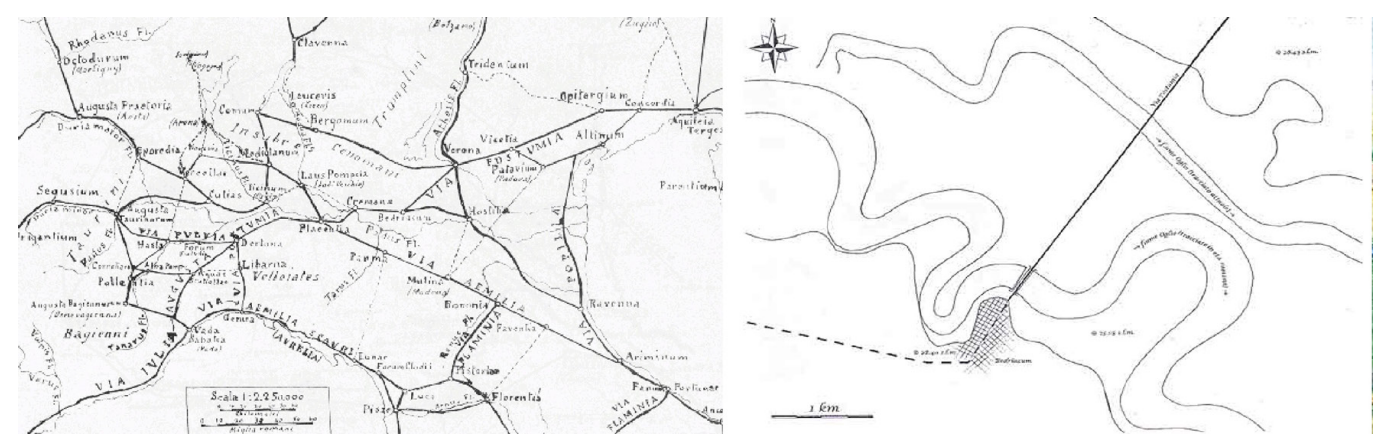

\section{Connettersi con la storia: il caso di Bedriacum a Calvatone (CR)}

La fondazione del vicus di Bedriacum risale alla seconda metà del II sec. a.C. e si inserisce nella fase di occupazione romana dei territori a Nord del fiume Po, durante la fondazione della colonia latina di Cremona, tra il 218 a.C. e il 190 a.C., e la creazione della via Postumia che collegava Genova ad Aquileia nel 148 a.C. [3]

Fondata come porto sul fiume Oglio, Bedriacum era un importante centro di scambio commerciale per tutta l'area padana tra la fine dell'età repubblicana e l'età imperiale. Nel 69 d.C., Bedriacum fu scenario per due battaglie, combattute in seguito alla morte di Nerone, dalle quali il vicus uscì completamente distrutto.

II sito archeologico di Bedriacum, oggi nei pressi della città di Calvatone in provincia di Cremona, diventa un'importante area di scavo nel 1836 con la scoperta della Vittoria Alata di Calvatone. Tra il XIX e il XX secolo vennero scoperti diversi resti che orientavano la struttura e il layout del vicus.

L'importanza storica e culturale del sito archeologico ha spinto ad avviare diverse indagini conoscitive, attraverso molteplici saggi esplorativi, a partire dal 1986 con l'inizio del Progetto Calvatone, che vede la collaborazione di diversi enti pubblici e università [4] al fine di definire l'intero impianto urbano del vicus di Bedriacum.

Ad oggi, dopo un ventennio di scavi condotti dai ricercatori dell'Università degli Studi di Milano, si concretizza la necessità di raccontare attraverso ambienti 3D virtuali l'evoluzione dello scavo archeologico. Tale ricerca è condotta in modo congiunto tra il Laboratorio di ricerca DAda-LAB dell'Università degli Studi di Pavia e il dipartimento di Beni Culturali dell'U- 
niversità degli Studi di Milano, cofinanziata dalla Regione Lombardia. La ricerca si propone di sviluppare, a partire dalla documentazione di scavo, un modello tridimensionale virtuale dell'evoluzione temporale degli scavi. In questo modo, il sito archeologico allo stato attuale non apprezzabile, poiché interrato, diviene visitabile e fruibile virtualmente attraverso un sistema informativo che supporti da un lato le attività proprie della ricerca, orientando le azioni interpretative degli archeologi, e dall'altro la promozione culturale e valorizzazione del sito stesso.

Fig. 3. A partire dalla sinistra, la Vittoria Alata di Ca vatone, scoperta nel 1836 Da quel momento, una serie di saggi esplorativ hanno portato alla luce le strutture urbane del vicus e elementi di pregio che sottolineano l'importanza storica ed economica de stontro urbano Sulla del centro urbano. Sulla destra il mosaico rinvenuto allinterno della Domus del Labinto, cosi denominata per la presenza di un emblema a mosaico con la raffigurazione di un labirinto
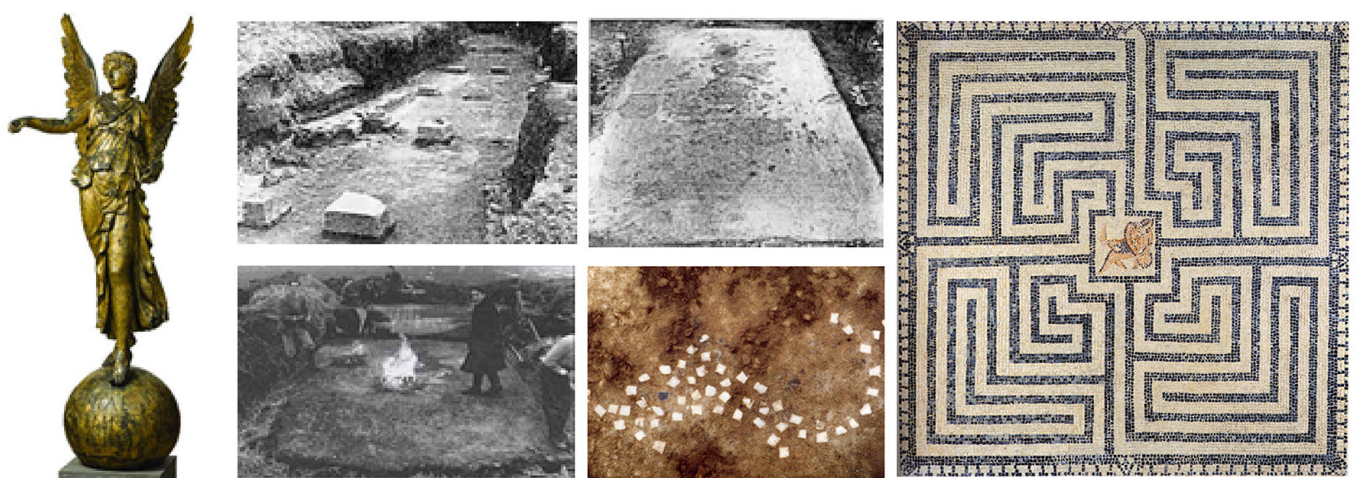

\section{Modelli tridimensionali e scenari virtuali}

La modellazione 3D del sito archeologico di Bedriacum si presenta come parte di una metodologia integrata [5] che ha come scopo la ricostruzione del passato. Partendo da una fase di documentazione [6], è possibile arrivare a definire un modello tridimensionale solo dopo aver studiato, analizzato e verificato ogni dato derivante da una campagna di scavo o da una fonte scritta. La ricostruzione tridimensionale, inserita successivamente all'interno di uno scenario virtuale, prova a offrire una traduzione visiva di un insieme di ricerche interdisciplinari che mirano a differenti obiettivi, tra cui la documentazione, la conservazione e la musealizzazione del bene. Inoltre, la produzione dei modelli tridimensionali va a supporto di analisi e interpretazioni per lo sviluppo di ipotesi ricostruttive, consentendo di realizzare strumenti informativi e modelli di Realtà Virtuale per la promozione e la narrazione del patrimonio archeologico in particolar modo quello non accessibile, ricostruendo la memoria storica di un luogo all'interno dell'ambiente digitale.
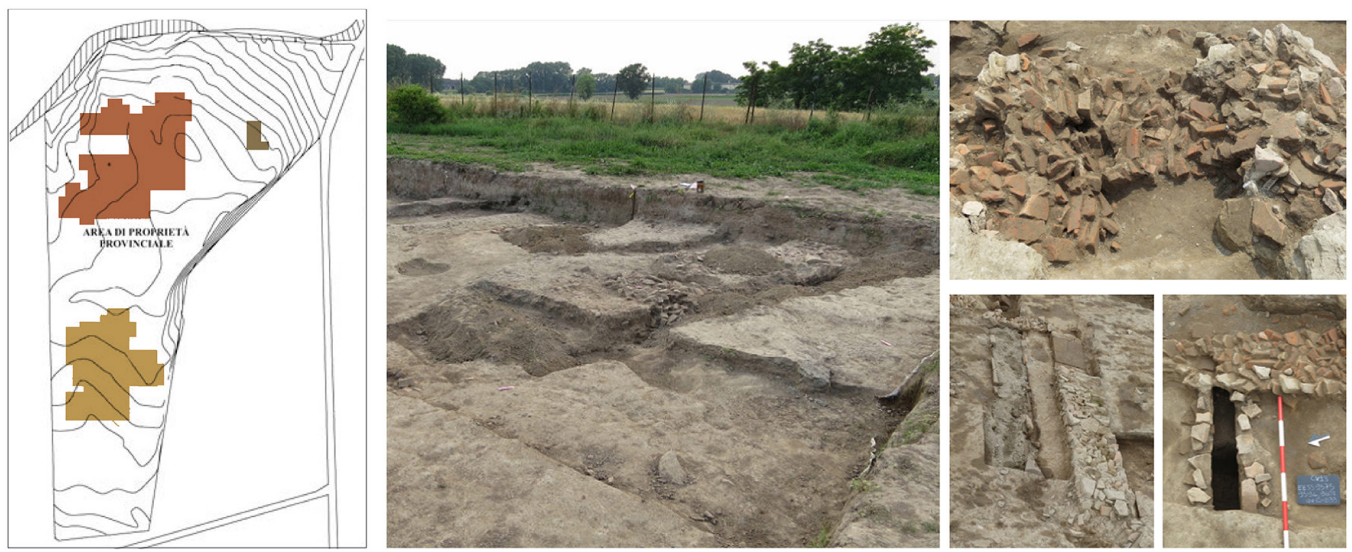

Fig. 4. A sinistra, l'evoluzione degli scavi effettuat dall'Università degli Studi di Milano nell'area di interesse. Sulla destra, immagini delle campagne di scavo con le relative strutture urbane portate alla luce da parte degli archeologi dell'Unive 


\section{Modelli semplificati per la comprensione delle volumetrie di scavo}

Partendo dalle rappresentazioni bidimensionali planimetriche dello scavo di Bedriacum in ambiente CAD, è stato possibile importare tali dati all'interno del software per la modellazione Rhinoceros e generare, tramite un processo di estrusione delle curve, delle poli-superfici NURBS. Inoltre, grazie alle quote altimetriche presenti sugli elaborati CAD, è stato possibile non solo ricollocare gli elementi di scavo alle quote in cui sono stati scoperti, ma anche modellare parte del terreno circostante. La modellazione è stata sviluppata seguendo l'ordine cronologico delle campagne di scavo effettuate dal 200 I al 20 I 8 e sovrapponendo le fasi di scavo attraverso punti in comune, ottenendo una prima stima dello sviluppo volumetrico dello scavo globale. Questo tipo di approccio ha permesso di ottenere una serie di vantaggi, tra cui:

a) una prima valutazione della volumetria del sito archeologico interrato e non visibile di Bedriacum, evidenziando non solo le singole strutture architettoniche del vicus, ma anche la loro correlazione con lo spazio circostante in cui sono presenti le altre strutture urbane; b) descrivere la storia del processo di scavo e documentazione, evidenziando, ove possibile, la continuità delle strutture presenti nel sottosuolo a diverse profondità, e fornendo una base valida all'analisi dell'evoluzione urbana del vicus per l'individuazione delle strutture non ancora scoperte.

c) ottenere delle sezioni dello scavo, non presenti allinterno degli elaborati bidimensionali, fornendo un valido supporto allo studio degli alzati delle strutture architettoniche e alle indagini delle stratigrafie.

Fig. 5. Porzione del modello 3D che descrive il volume di scavo e i rest archeologici realizzata dei disegni 2D.
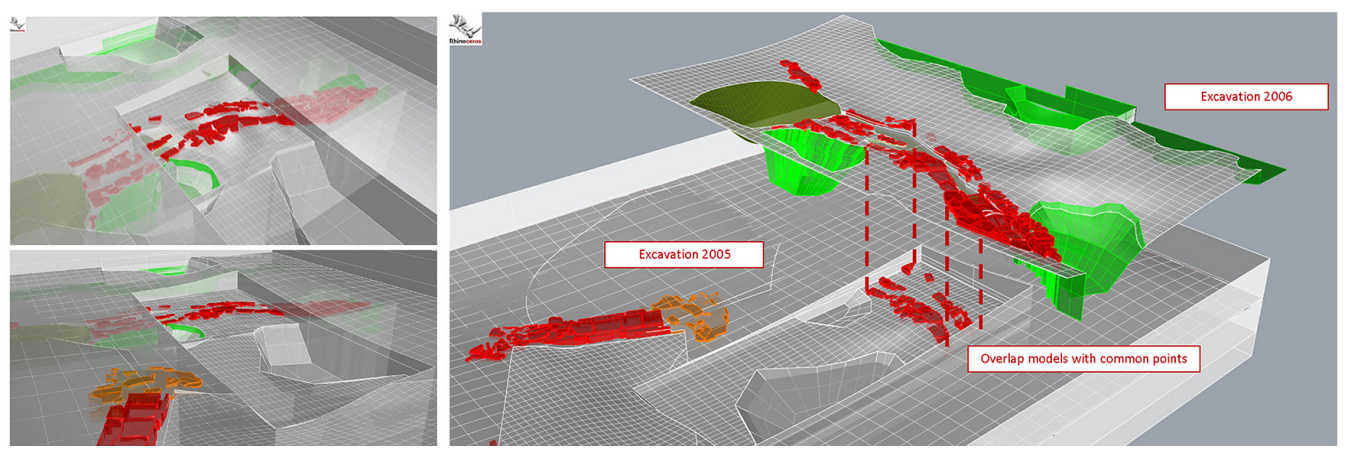
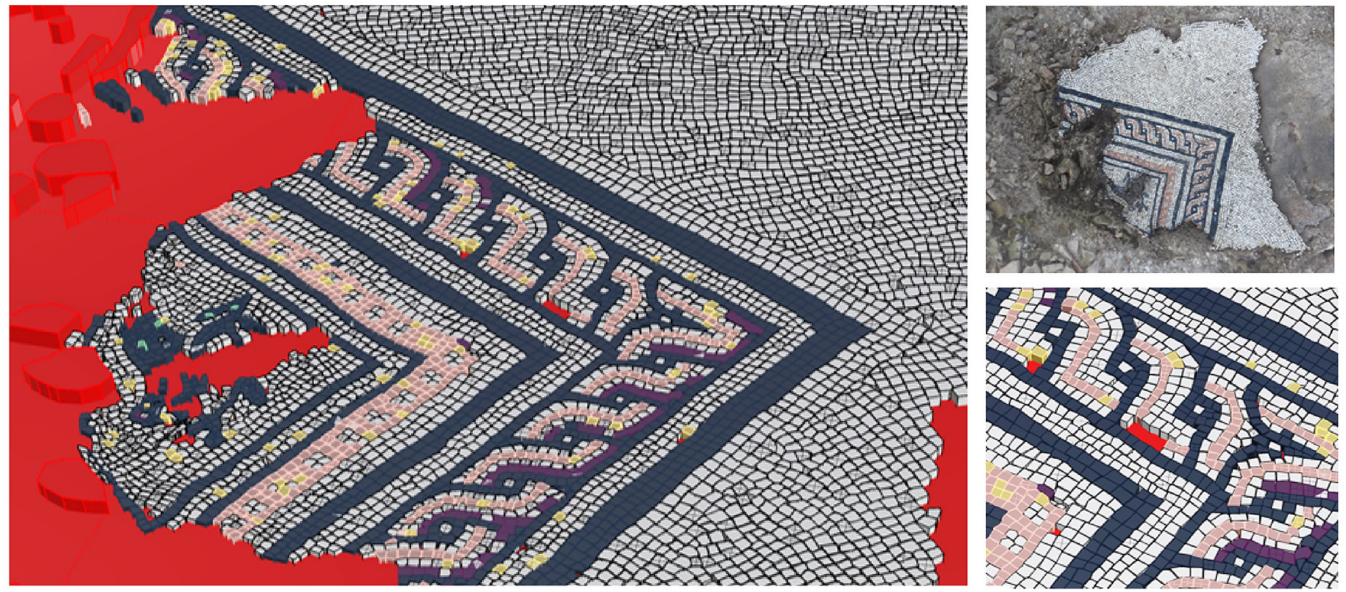


\section{Modelli fotogrammetrici per la costruzione di scenari virtuali}

Se da un lato il modello semplificato consente una lettura agevolata del contesto di scavo, la modellazione tridimensionale fotogrammetrica permette di comprendere e valutare una maggiore quantità di informazioni legate principalmente alle caratteristiche geometriche, cromatiche e materiche del manufatto. Nel modello semplificato, una singola struttura diviene un segno iconico di un complesso insieme di elementi, che diventano leggibili grazie ad una rappresentazione che si "avvicina al modello percettivo che costruiamo nel conoscere e nel ricordare l'oggetto mediante esperienza reale e diretta" [Capucci 1993, p. 43].

Attraverso la modellazione fotogrammetrica è stato possibile ricreare parte degli elementi di scavo tramite la documentazione fotografica. Attraverso l'uso di Agisoft Metashape, dedicato alla ricostruzione fotogrammetrica, i modelli tridimensionali composti da mesh hanno soddisfatto una prima finalità dimostrativa in virtù dell'alta vero-somiglianza con l'oggetto ripreso. Tramite questo tipo di modellazione è stato possibile approfondire le informazioni riguardanti letture tipologiche delle strutture presenti nel vicus e la complessa composizione degli elementi di scavo, che a volte non sono ben distinguibili e classificabili. Parallelamente alle considerazioni di tipo puntuale su un unico elemento di scavo, esattamente come per la modellazione semplificata, è stato possibile definire un quadro di insieme degli elementi di scavo. L'allineamento dei diversi modelli è avvenuto sulla base di punti referenziati sul dato vettoriale CAD, ottenendo degli errori di allineamento nell'ordine del centimetro, causati principalmente dalla mancanza di quote altimetriche degli elementi e dalla discretizzazione intrinseca nel ridisegno degli elementi. Nonostante questo, ai fini della ricerca, è stato possibile definire in maniera più dettagliata e con maggiore cura i rapporti di spazialità tra le porzioni di scavo.

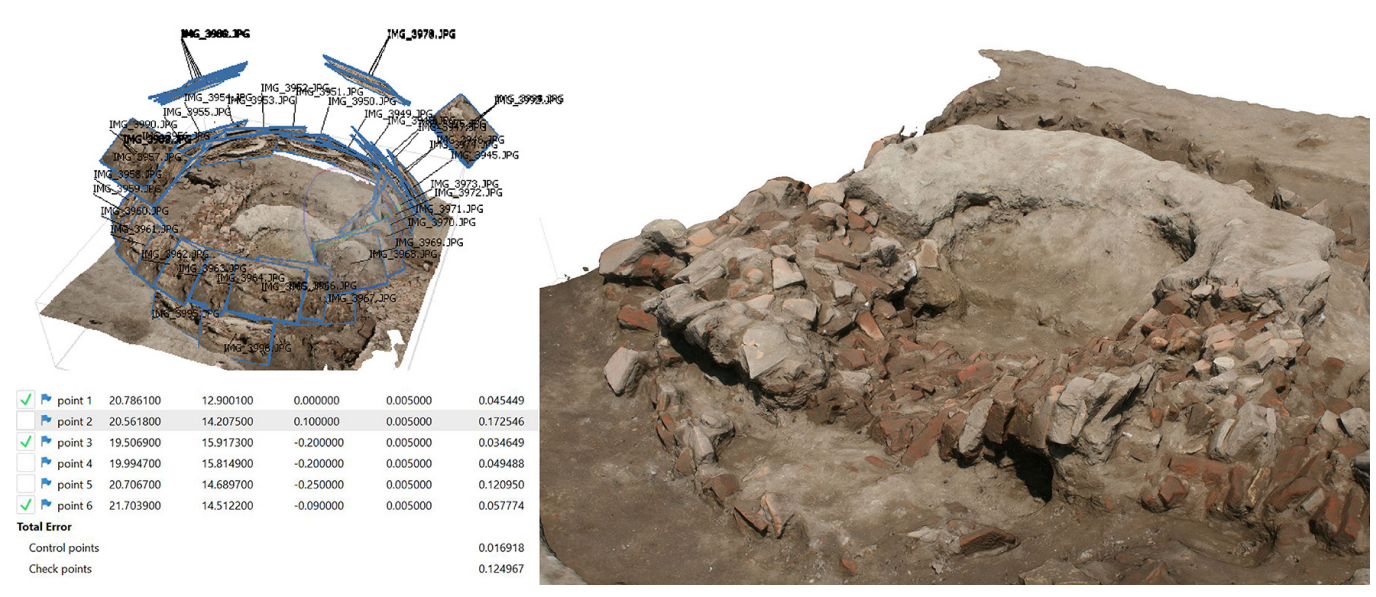

\section{Scenari virtuali per la narrazione dello scavo}

Nel caso di Bedriacum la ricostruzione tridimensionale delle fasi di scavo, suddivise per anni, ha permesso di sviluppare poi una narrazione per ambienti, destinata ad una seconda fase del progetto di ricerca. Sono state effettuate due differenti sperimentazioni importando dapprima il modello semplificato degli scavi all'interno del software Unity 3D e successivamente il modello fotogrammetrico in ambiente Unreal Engine 4.0. Quest'ultimo, attraverso una programmazione visuale del sistema virtuale, ha permesso di ottenere un primo risultato ai fini della comunicazione delle fasi di scavo, confermando l'influenza grafica e percettiva del modello fotogrammetrico, rispetto a quello semplificato.

Per ciò che riguarda la programmazione, in entrambe le piattaforme è stato necessario programmare l'interfaccia dell'utente [7] per la fruizione attraverso sistemi Oculus Rift e Oculus Touch. Successivamente la programmazione ha riguardato anche l'inserimento di elementi 
tridimensionali interrogabili che permettono di visualizzare o nascondere lo scavo in relazione ai diversi anni e alle diverse azioni intraprese all'interno del sito archeologico, creando così una mappa temporale interattiva in grado di descrivere la storia delle indagini condotte. Se da un lato la programmazione in unity è risultata di facile utilizzo, grazie anche agli strumenti di base che il software offre, dall'altro la programmazione visuale blueprint di Unreal Engine 4 è dipesa dalle basi di conoscenza sulle interfacce e gli schemi grafici di questo software. Nonostante questo, l'interfaccia grafica di UE4 si è configurata come la migliore alternativa per lo sviluppo dell'applicazione di Realtà Virtuale per Bedriacum.

II risultato è stato una prima applicazione di Realtà Virtuale, fruibile interamente con sistemi Oculus, ha permesso di muoversi all'interno dell'area di scavo e di cliccare su elementi tridimensionali che indicano l'anno di scavo e consentono di mostrare o nascondere gli scavi, principalmente nell'area in cui gli archeologi hanno portato alla luce le strutture urbane di Bedriacum tra il 2005 e il 2018 [8].

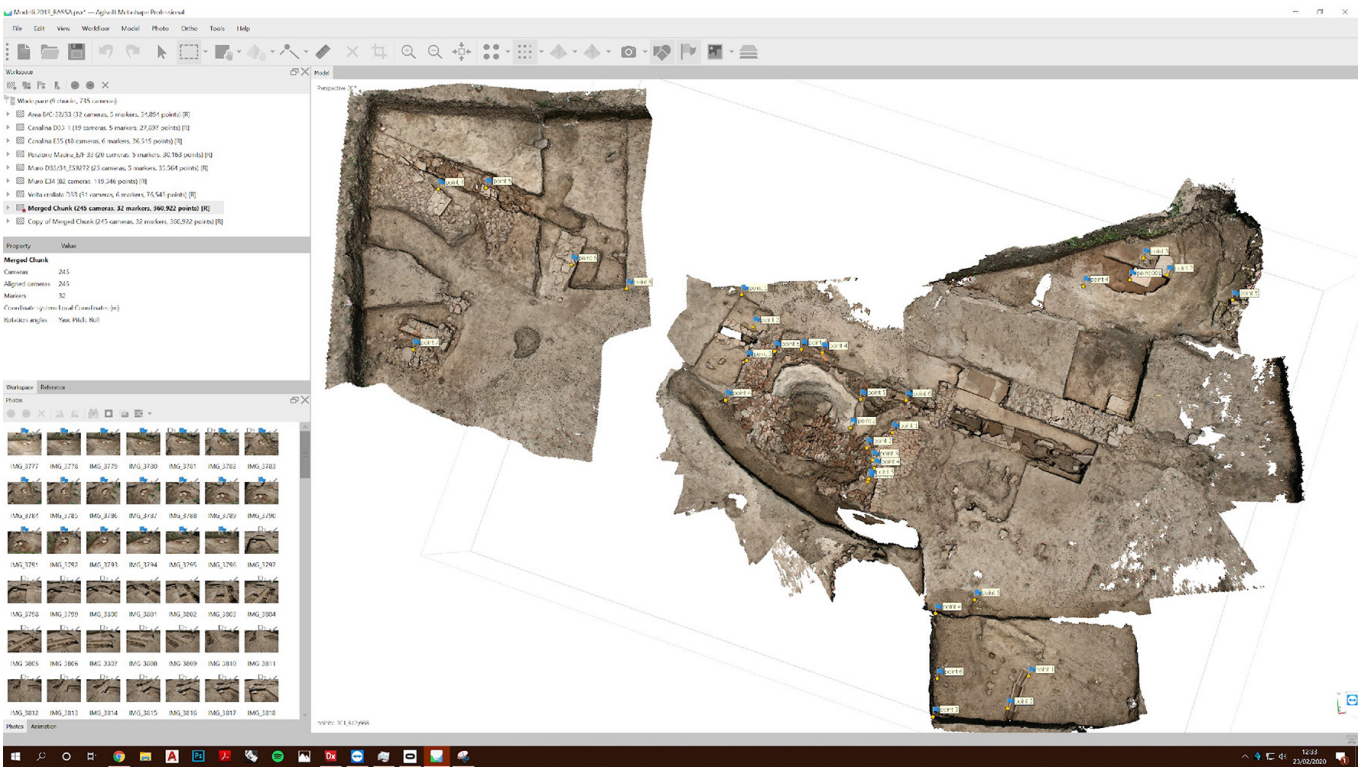

Fig. 9. Visualizzazione del modelli fotogrammetric all'interno del software Unreal Engine 4.
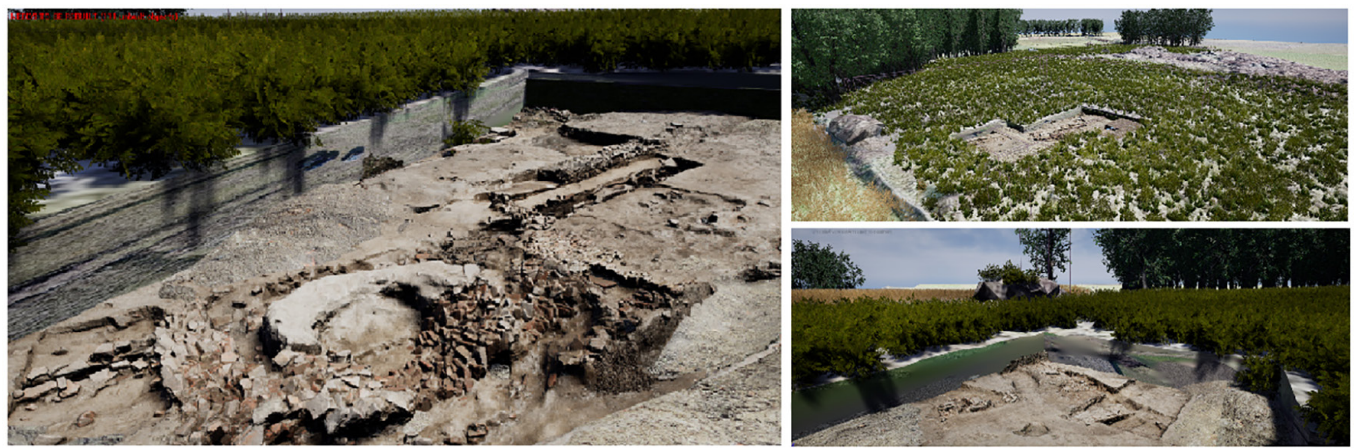
Fig. 10. Programmazione visuale Blueprint peri caso di Bedriacum. La formattazione grafica permette un controllo più accurato delle diverse funzioni di programmazione.
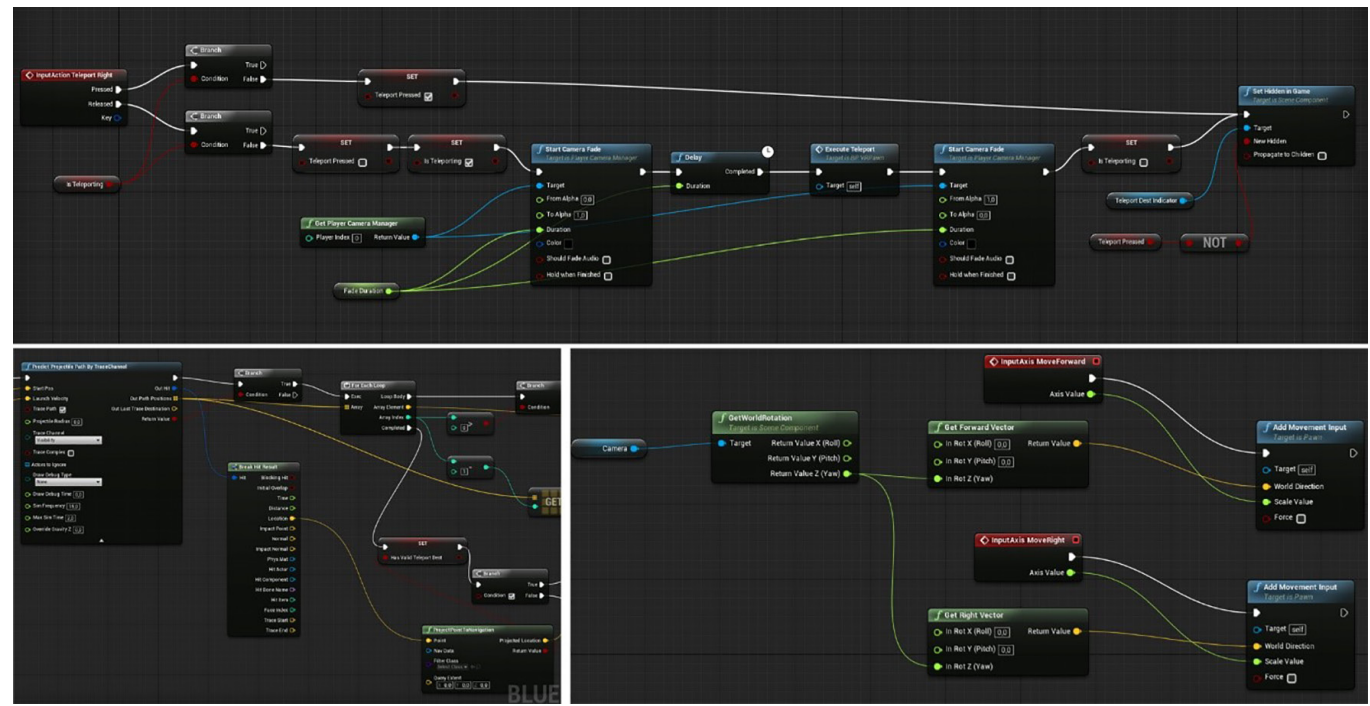

\section{Sviluppi futuri}

Così come sintetizzato nei precedenti paragrafi, i modelli e le rappresentazioni tridimensionali risultano di fondamentale importanza ai fini della comunicazione e dell'analisi dei reperti archeologici, siano essi intesi come strutture architettoniche o singoli manufatti artigianali. L'utilizzo della Realtà Virtuale, in cui si inseriscono i nuovi sistemi tridimensionali di rappresentazione dello spazio del vicus, consentirà di configurare luoghi ed oggetti attraverso la caratterizzazione dei segni e l'implementazione del dato digitale mediante testi, immagini e suoni. Attraverso la visita virtuale del sito e del bene architettonico rilevato e virtualizzato, sarà possibile interagire con uno spazio ricostruito in funzione di ipotesi ed interpretazione dei resti. Infine, partendo da considerazioni di tipo storico-costruttive, grazie ai sistemi virtuali sarà possibile riconfigurare le ambientazioni del vicus, generando un nuovo sistema divulgativo e comunicativo delle caratteristiche del patrimonio archeologico di Bedriacum.

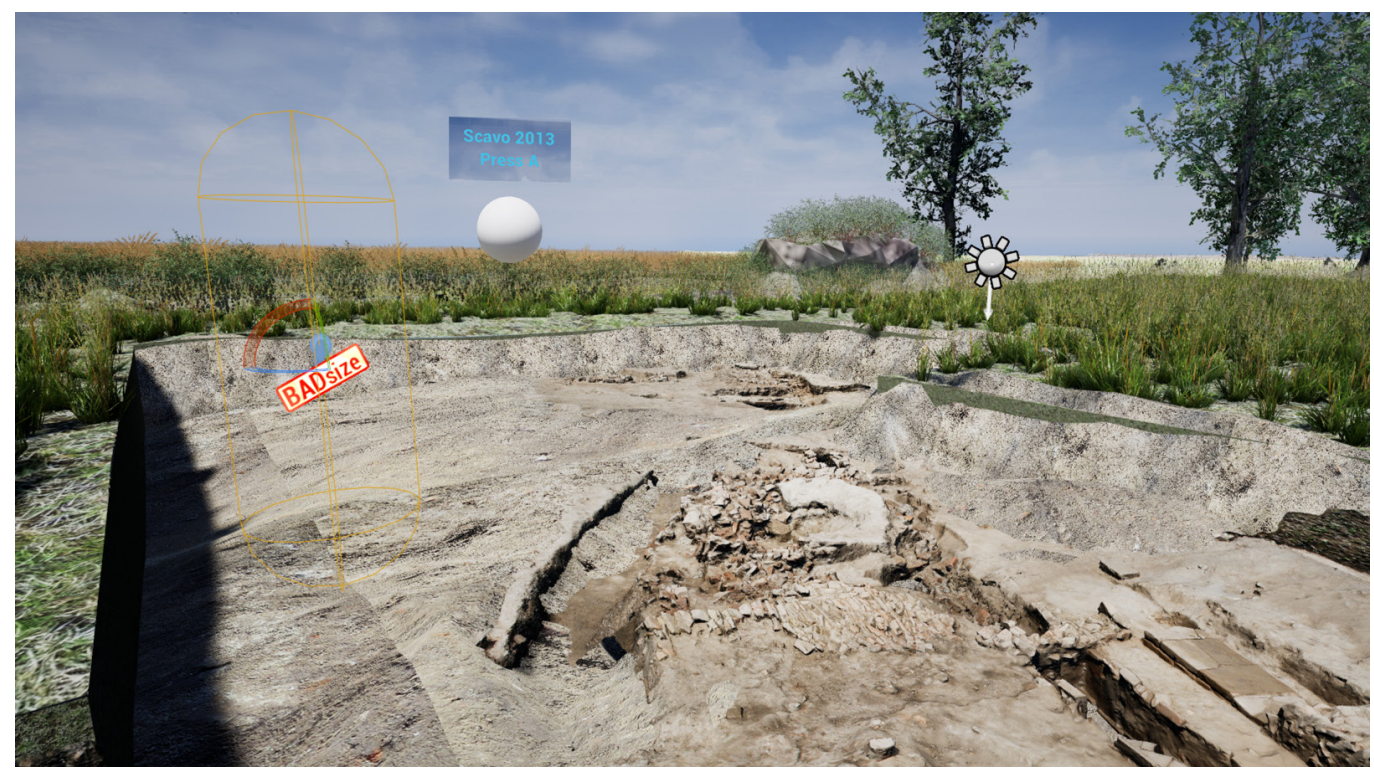




\section{Note}

[I] Nel 1994 Paul Mulgram e Fumio Kishino illustrarono il concetto di Realtà Mista in quello che successivamente venne definito come Reality-Virtuality (RV) Continuum, cioè quella scala di valori che va tra il "virtuale" e il "reale" all'interno della Mixed Reality. Si veda: Milgram, Kishino 1994, pp. I 321 - 1329.

[2] "What does the term virtual archaeology mean here? The key concept is virtual, an allusion to a model, a replica, the notion that something can act as a surrogate or replacement for an original. In other words, it refers to a description of an archaeological formation or to simulated archaeological formation. (A simulated data set will normally be shaed by the criteria used for recording an actual formation). The problem is therefore to identify the quintessential components of the archaeological formation under investigation. All have implications for data representation and information handling": Reilly Paul. I 99 I. Towards a Virtual Archaeology. In Rahtz, S. and K. Lockyear (1990). Computer Applications and Quantitative Methods in Archaeology. Oxford: Tempus Reparatum, pp. I33139.

[3] La presenza del vicus è confermata da molteplici fonti storiche. In particolare "inter Veronam Cremonamque situs est vicus, duabus iam Romanis cladibus notus infaustusque" tratto daTacito, Historiae, II Libro.

[4] II Progetto Calvatone è stato avviato nel 1986 in collaborazione con la Soprintendenza Archeologica della Lombardia, Istituto di Archeologia dell'Università degli Studi di Milano, Istituto di Archeologia dell'Università degli Studi di Pavia.

[5] La metodologia integrata ha previsto diverse azioni documentative dell'area di scavo attraverso strumentazione digitale Laser Scanner a stazione fissa (FARO Focus SI50) e Laser Scanner mobile (Kaarta Stencil) e una fase di acquisizione dei dati territoriali attraverso l'utilizzo di sistemi UAV. Dall'integrazione di questi dati, è stato sviluppato un primo modello tridimensionale mesh dell'area in cui inserire gli elementi di scavo.

[6] Nel caso specifico di Bedriacum, la documentazione è composta da un archivio fotografico delle campagne di scavo e dei rilievi topografici dell'area di scavo, nonché dei dati vettoriali delle strutture portate alla luce.

[7] Per il software Unity 3D, la programmazione è avvenuta tramite codici C\# sviluppati da Unity. Differentemente, per Unreal Engine 4.0 si è preferito avvalersi di guide e manuali per la programmazione visuale blueprint, tra cui Kevin Mack, Robert Ruud, 2019, Unreal Engine 4Virtual Reality Projects: Build immersive, real-world VR applications using UE4, C++, and Unreal Blueprints, Packt Publishing, 2019, pp 632.

[8] La documentazione degli scavi antecedenti non consente uno sviluppo dei modelli fotogrammetrici, in quanto l'archivio fotografico non è stato sviluppato per questa metodologia. L'integrazione dei modelli 3D degli scavi che vanno dal 2001 al 2004 avverrà in una seconda fase di ricerca in cui verranno texturizzati i modelli semplificati.

\section{Riferimenti bibliografici}

Asif Ali (20 I6). Virtual Archeology: Experiencing the Past Through Technology. In Indian Journal of Archeology, I, 3, pp. $332-337$.

Bacchetta Alberto, Grassi Maria Teresa (20 I0). Dalla "Domus del Labirinto" al "Quartiere degli Artigiani”. Nuove scoperte a Calvatone Romana. In Documenta Antiquaris. Atti di Seminari di Dipartimento, pp. 27-54.

Capucci Pier Luigi (1993). Reale e Virtuale. Rappresentazioni tecnologiche, comunicazione, arte. Bologna: Clueb, p. 43.

Champion Erik (2008). Explorative Shadow Realms of Uncertain Histories. In Yehuda Kalay, Thomas Kvan, Janice Affleck (eds.). New Heritage: New Media and Cultural Heritage. London: Routledge, pp. I 85-206.

Forte Maurizio, Beltrami Roberta (2000). A proposito di Virtual Archaeology: disordini, interazioni cognitive e virtualità. In Archeologia e Calcolatori, I I. pp. 273-300.

Yu Hookk Daria (2016). "From illusion to reality: trasformation of the term "virtual archeology". In Archeological and Anthropological Sciences, 8, 4, p. 647.

Gabellone Francesco (2014). Digital Technologies and Communication: Prospects and Expectations. In Open Archaeology, pp. $102-118$.

Gabellone Francesco (2013). II santuario di Giove Anxur a Terracina. Una ricostruzione tipologica come ausilio alla visita in situ. In Virtual Archaeology Review, 4, 9, pp. $108-115$.

Guidazzoli Antonella, Liguori Maria Chiara (200I). Realtà virtuale e Beni culturali: una relazione in evoluzione vista attraverso i progetti sviluppati presso il Cineca. In Storia e Futuro, 25, 201 I, pp. 2-26.

Guidi Gabriele, Russo Michele, Angheleddu Davide (2014). 3D survey and virtual reconstruction of archeological sites. In Digital Applications in Archeology and Cultural Heritage, I, 2, pp. 55-69.

Losier Louis Martin, Pouliot Jacynthe, Fortin Michael (2007). 3D geometrical modeling of excavation units at the archaeological site of Tell 'Acharneh (Syria). In Journal of Archaeological Science, 34, 2, pp. 272-288.

Milgram Paul, Kishino Fumio (1994). A Taxonomy of Mixed Reality Visual Displays. In IEICE Transactions on Information and Systems, E77-D, 12, pp. I321-1329.

Parrinello Sandro, Bercigli Monica, Bursich Daniele (2017). From survey to 3d model to "videogame". The virtual reconstruction of a Roman Camp in Masada, Israel. In DisegnareCon, 10, 19.

Parrinello Sandro, Picchio Francesca (20/4). Dalla fotografia digitale al modello 3D dell'architettura storica. In DisegnareCon, La fotografia digitale, I2, pp. I- I 4. 
Parrinello Sandro, Picchio Francesca, Bercigli Monica. (2017). La 'migrazione' della realtà in scenari virtuali: Banche dati e sistemi di documentazione per la musealizzazione di ambienti complessi. In DisegnareCon, Musei virtuali dell'architettura e della città, $17,14.1-14.8$

Parrinello Sandro, Picchio Francesca (2017). Database and Complexity. Remote use of the data in the virtual space of reliable $3 \mathrm{D}$ models. In Architecture and Engineering, 2, 2, pp. 27-36.

Parrinello Sandro, Picchio Francesca, Dell'Amico Anna (2019). When the Future Is the Past. Digital Databases for the Virtualization of Museum Collection. Proceedings of the Ist International and Interdisciplinary Conference on Digital Environments for Education, Arts and Heritage, EARTH 20 8. Bressanone, 5-6 luglio.

Ragni Maddalena (2008). La valorizzazione dei siti archeologici. Obiettivi, strategie e soluzioni. In MiBaCT. La valorizzazione dei siti archeologici. Obiettivi, strategie e soluzioni. Roma: Edizioni MP Mirabilia, p. 6-2I.

Remondino Fabio (20II). Heritage Recording and 3D Modeling with Photogrammetry and 3D Scanning. In Remote Sensors, 3, 6, pp. $1104-1138$

\section{Autore}

Francesca Galasso, Università degli Studi di Pavia, francesca.galasso@unipv.it

Per citare questo capitolo: Galasso Francesca (2020). La realtà virtuale per il racconto dell'Archeologia. Bedriacum 3D: il disegno per la narrazione di un vicus interrato/Virtual reality for the discovery of Archaeology. Bedriacum 3D: drawing for the narration of a buried vicus. In Arena A., Arena M., Brandolino R.G., Colistra D., Ginex G., Mediati D., Nucifora S., Raffa P. (a cura di). Connettere. Un disegno per annodare e tessere. Atti del $42^{\circ}$ Convegno Internazionale dei Docenti delle Discipline della Rappresentazione/Connecting. Drawing for weaving relationships. Proceedings of the 42th International Conference of Representation Disciplines Teachers. Milano: FrancoAngeli, pp. 2204-2223. 


\title{
Virtual Reality for the Discovery of Archaeology. Bedriacum 3D: Drawing for the Narration of a Buried Vicus
}

\author{
Francesca Galasso
}

Abstract

With the advent of the new applications of Virtual Reality and Augmented Reality, the archaeological research and the communication of data of the excavations have been undergoing a new phase of development in the creation of databases. Three-dimensional models are now interactive and encourage the development of new strategies for the communication, narration and dissemination of the archaeological heritage. Virtual Archeology, based on interactive three-dimensional models, not only allows to understand the development and the phases of archaeological excavations, but also to simulate three-dimensional reconstructions of an environment in a reconfiguration which is different from the current one. Starting from an accurate historical analysis of the elements and structures of the excavation, it is possible to generate a visual "model of knowledge", populated with information and multimedia contents that allow to deepen and narrate inaccessible archaeological contexts.

The creation of virtual 3D environments, aimed not only at dissemination and education but also at historical and architectural analysis and understanding, is one of the objectives of research study conducted by the DAda-LAB laboratory of the University of Pavia on the archaeological site of Bedriacum, a Roman vicus near Calvatone, in the province of Cremona. The twenty year-long excavations, carried out on-site by archaeologists from the University of Milan, have brought to light the remains of an urban system consisting of villas and structures dating between the second century. B.C. and the 5th century A.D.

Keywords

Virtual Archeology, 3D models, Virtual Reality, digital representation, Bedriacum.

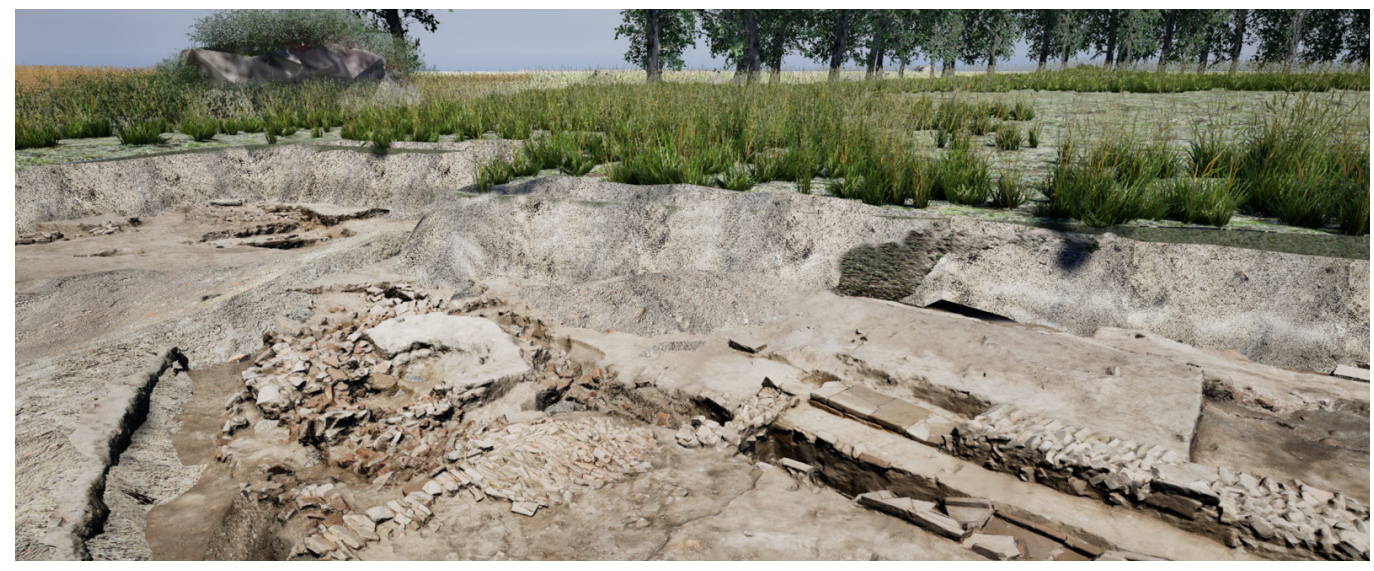




\section{Communicating history in the digital age: Virtual Heritage and Virtual Archeology}

The multiplication of identities, individuals as well as cultural heritage, which in the last years of the digital era has revolutionized social and cultural interaction, offers numerous food for thought to contextualize and rethink the role of models for the enhancement of cultural contexts and, more generally, to define alternative tools for the use of knowledge.

The digitalization of cultural heritage has made it possible to create searchable and metric reliable databases to allow the operators involved in the documentation processes to respond to the needs and issues of managing cultural heritage. This digital legacy represents the main starting point in the disclosure of complex and heterogeneous information regarding cultural heritage.

Virtual Reality applications in the field of Cultural Heritage describe an information offer that seeks to use the virtual as a means for enhancing the real. By amplifying the specificities of a given phenomenon, the construction of multimedia systems allows for a more detailed and more personal use of museum content. The possibility of interconnecting data in a space located in the network allows you to create connections to develop attractive paths for a specific context by a specific user.

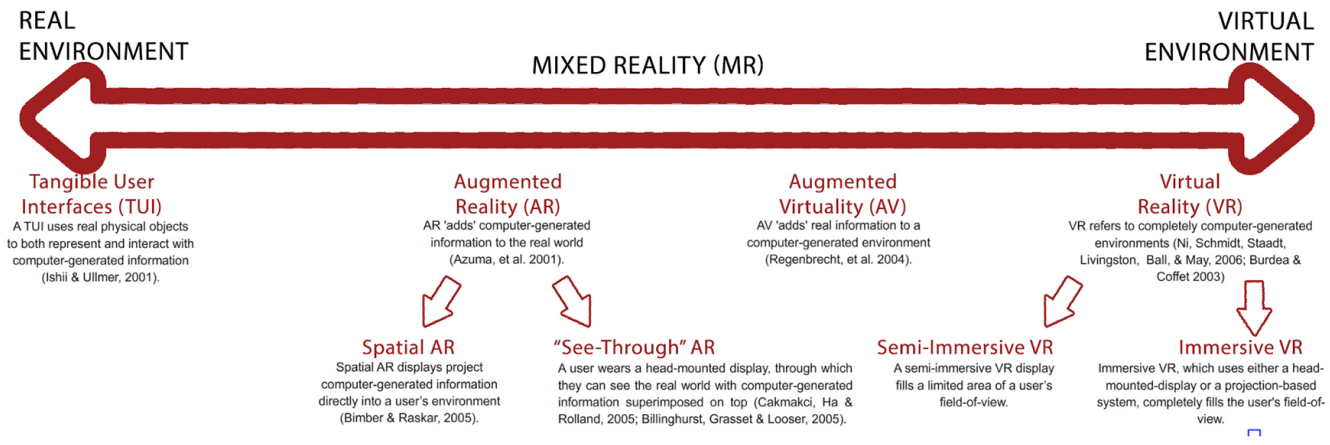

Disciplines such as history, architecture and archeology are experiencing the use of Virtual Reality, Augmented Reality and Mixed Reality [I] technologies for the enhancement of works mainly according to two different methodologies: on the one hand, by placing virtual three-dimensional objects in real contexts, integrating different types of information, on the other hand by reconstructing plausible environments usable through Head Mounted Display (HMD) systems. The use of simulation techniques, immersive technologies and researchable three-dimensional reconstructions responds to one of the fundamental objectives of Virtual Heritage: "to convey not just the appearance but also the meaning and significance of cultural artefacts and the associated social agency that designed and used them" [Champion 2008 pp. 185-206].

Currently, in the archaeology area, there is an increasingly frequent use of information technology: from field investigations, to data collection, to the historical reconstruction of events and development phases of lost cultures. In this sense, Virtual Heritage translates into Paul Reilly's Virtual Archeology [2].

The virtual reconstruction of the archaeological heritage is one of the most innovative tools for preserving the historical memory of places, relating the traces belonging to past eras. The possibility of observing what is no longer allows to transform "from imaginary to existing into our understanding" [Yu Hookk 2016, p. 647], thus being able to put the memory in contact with those who enjoy a certain space.

This process implies that the models are configured as the result of an encoding activity of the material signs present on the site and of the information available in historical or archival documents. 
Fig. 2. Historical framework of the Roman vicus of Bedriacum. The historical maps show the vicus was located on via Postumia, with particular attention to its presence near the Oglio River:
So, in the digital model time stops and multiplies, favoring that museum configuration whereby archaeological sites and museums "are considered places where historical and artistic memory is preserved over time [...] contributing to the dissemination of knowledge and culture" [Ragni 2008, pp. 2-26].

The threats that loom over a digital space, in terms of compromising its ability to persist over time, are different from those of a real space. The methods of duplicating and relocating a database in numerous archives mean that today the digital space is probably somehow more secure and the information contained in an archive, whether this is an information model or a data connection platform, can be visited and put in relationship with many more users than can happen for a real place, bound among many, to its location in a specific place. For this reason, virtual archeology presents itself as the result of the application of various researches / projects in the context of interdisciplinary studies. Virtual Reality is proposed not only as a magnifying glass for the analysis and study of excavation structures or exhibits, but also as a "visual portal" [Guidazzoli, Liguori 20I I, pp. 2-26] of the past. In fact, through three-dimensional reconstructions of ancient settings, deriving from hypotheses and historical analyzes, researchers and users can obtain different types of information, at different scales of detail of the selected settings.

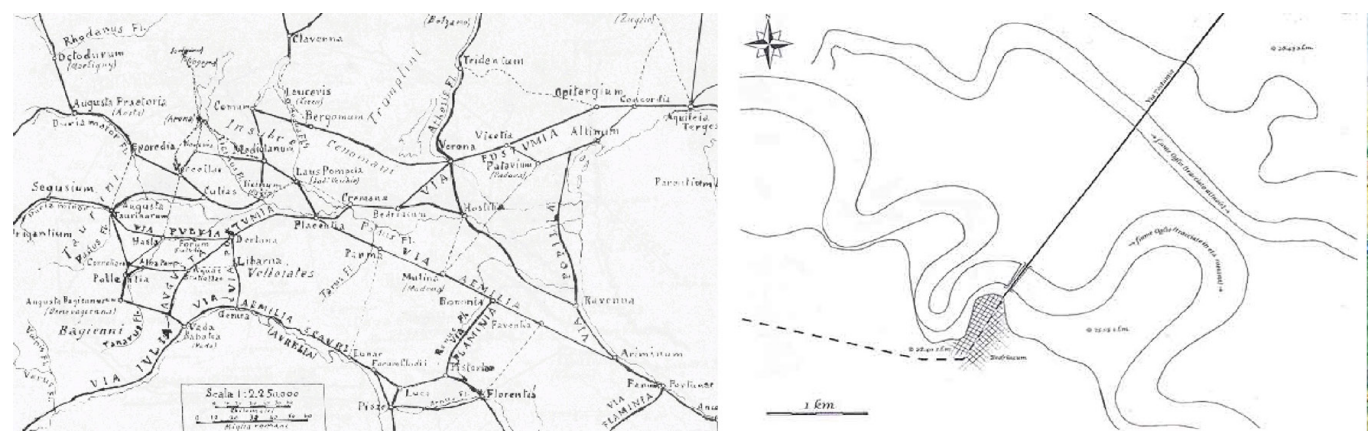

\section{Connecting with history: the case of Bedriacum in Calvatone (CR)}

The foundation of the vicus of Bedriacum dates back to the second half of the second century B.C. and is part of the Roman occupation phase of the territories north of the river Po, during the foundation of the Latin colony of Cremona, between 218 BC and 190 BC, and the creation of the Via Postumia that connected Genoa to Aquileia in I48 B.C. [3].

Founded as a port on the Oglio river, Bedriacum was an important commercial exchange center for the Po area between the end of the republican age and the imperial age. In 69 A.D., following the death of Nero, Bedriacum was the setting of two battles, in which the vicus was destroyed.

The archaeological site of Bedriacum, today near the city of Calvatone in the province of Cremona, became an important excavation area in 1836 with the discovery of the Winged Victory of Calvatone. Between the $X I X$ th and $X X$ th centuries, a number of remains were discovered and they helped in defining the structure and the layout of the vicus.

The historical and cultural importance of the archaeological site has prompted the launch of various cognitive investigations, through multiple exploratory surveys, starting in 1986 with the beginning of the "Calvatone project", which sees the collaboration of several public authorities and universities [4], in order to define the entire urban layout of the Bedriacum vicus.

Today, after twenty years of excavations carried out by researchers from the University of Milan, the need to tell the evolution of the archaeological excavation through virtual 3D environments is taking shape. DAda- $L A B$ research laboratory of the University of Pavia 
and the Department of Cultural Heritage of the University of Milan, conduct the research study, which is co-financed by the Lombardy Region. Starting from the excavation documentation, the research study aims to develop a virtual three-dimensional model of the temporal evolution of the excavations. Being buried, the site is currently not accessible, but the information system, now under development, will make it possible to virtually visit it, thus supporting research activities, guiding the interpretative actions of archaeologists and, ultimately, valorising the site itself.

Fig. 3. On the left, Winged Victory of Calvatone, found in 1835. Since that date, a number of excavations brought to light the layout of the vicus and a great of fine elements highlighting the historical and economic importance fight the mosac On the right, the mosaic found inside the "Domus of the Labyrinth", named after the labyrinth, represented on the mosaic itself.
Fig. 4. On the left, the evolution of the excavations carried out by the University of Milan in the area of interest. On the right, images of the excavation campaigns with the related urban structures brought to light by archaeologists from the University of from
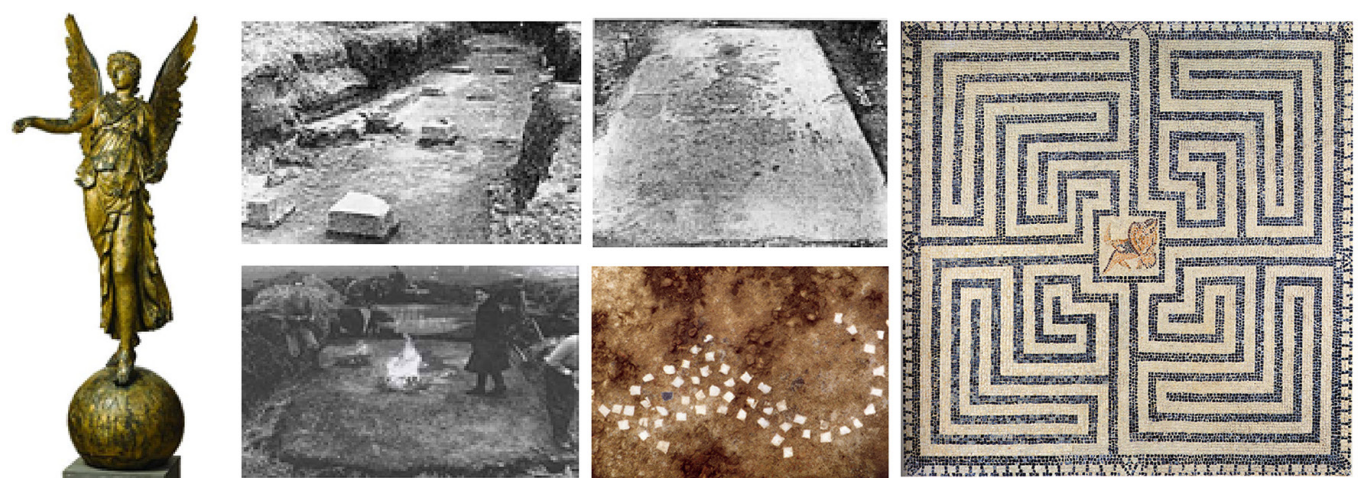

\section{Three-dimensional models and virtual scenarios}

The 3D reconstruction of an archaeological site is part of an integrated methodology [5] that aims to reconstruct the past, without neglecting any of its aspects. The definition of a three-dimensional model, starting from the documentation phase [6], is only feasible after having studied, analyzed and verified any data deriving from an excavation campaign or a written source. The three-dimensional reconstruction, then integrated within a virtual scenario, tries to offer the visual translation of a set of interdisciplinary research works that aim at different objectives, including the documentation, conservation and museum display of the archaeological heritage. In addition, the production of three-dimensional models supports analyses and interpretations for the development of reconstructive hypotheses, allowing the creation of information tools and Virtual Reality models for the promotion and narration of the archaeological heritage, especially the inaccessible one, by reconstructing the historical memory of a place within the digital environment.
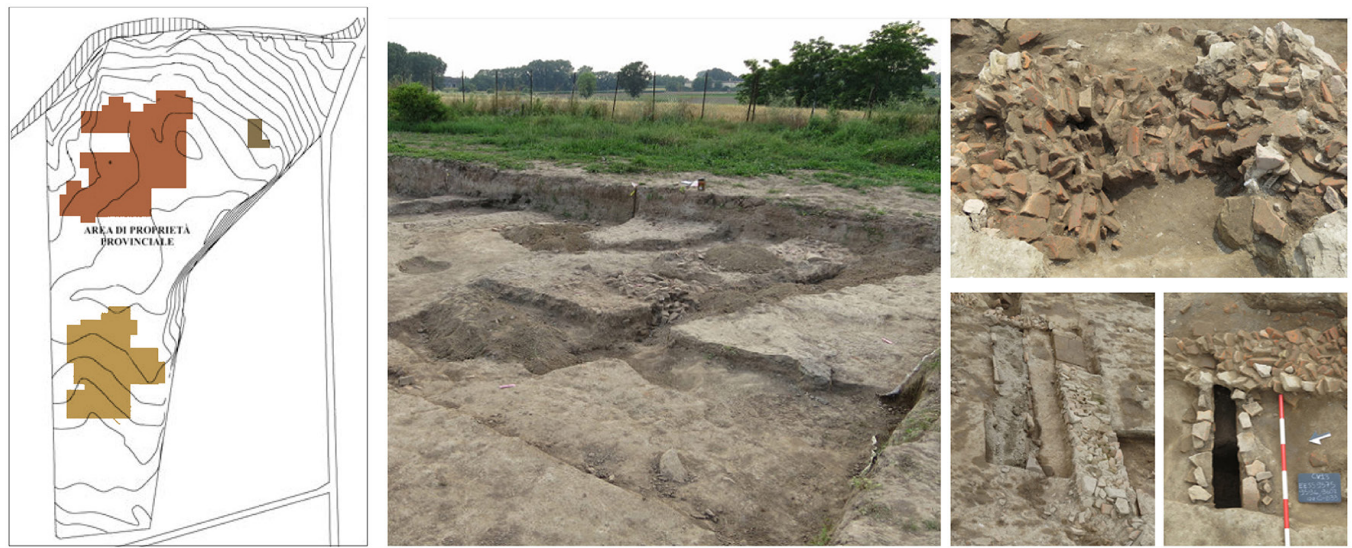


\section{Simplified models for understanding the excavation volumes}

Starting from the two-dimensional planimetric representations of Bedriacum excavation in the CAD environment, it was possible to import this data into the Rhinoceros modeling software and generate, through a process of extrusion of the curves, of the NURBS poly-surfaces. Furthermore, thanks to the altimetric dimensions present on the CAD drawings, it was possible not only to relocate the excavation elements to the dimensions in which they were discovered, but also to model part of the surrounding terrain. The modeling was developed following the chronological order of the excavation campaigns carried out from $200 \mathrm{I}$ to 2018 and superimposing the excavation phases through common points, obtaining a first estimate of the volumetric development of the global excavation. This type of approach has made it possible to obtain a series of advantages, including:

a) first evaluation of the volume of the underground and invisible archaeological site of Bedriacum, highlighting not only the individual architectural structures of the vicus, but also their correlation with the surrounding space in which the other urban structures are present;

b) describe the history of the excavation and documentation process, highlighting, where possible, the continuity of the structures present in the subsoil at different depths, and providing a valid basis for analyzing the urban evolution of the vicus for identifying undiscovered structures.

c) obtain sections of the excavation, not present within the two-dimensional drawings, providing valuable support for the study of the elevations of the architectural structures and investigations of the stratigraphies.

Fig. 5. Portion of the 3D model that describes the excavation volume and the archaeological remains created by modeling the $2 \mathrm{D}$ drawings.
Fig. 6. Detail of the three-dimensional recon struction of a portion of the mosaic found during one of the excavations.
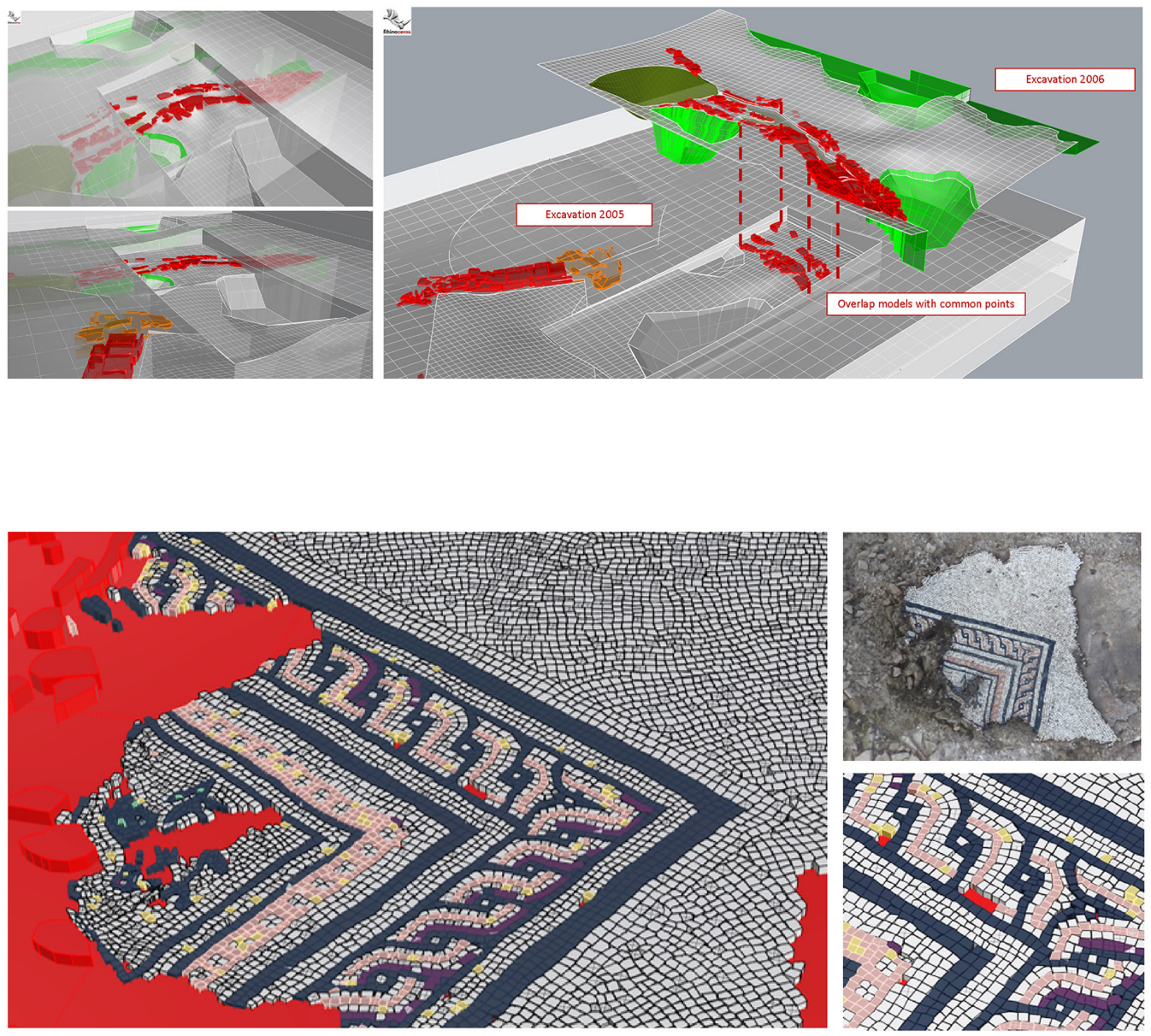


\section{Photogrammetric models for the construction of virtual scenarios}

If on the one hand the simplified model allows an easier reading of the excavation context, the three-dimensional photogrammetric modeling allows to understand and evaluate a greater quantity of information related mainly to the geometric, chromatic and material characteristics of the building. In the simplified model, a single structure becomes an iconic sign of a complex set of elements, which become legible thanks to a representation "that approaches the perceptual model that we build in knowing and remembering the object through real and direct experience" [Capucci 1993, p. 43].

Through the photographic documentation it was possible to recreate part of the excavation elements. Through the use of Agisoft Metashape, dedicated to photogrammetric reconstruction, the three-dimensional models composed of mesh satisfy a first demonstration purpose by virtue of the high true resemblance to the photographed object. Through this type of modeling it was possible to deepen the information regarding typological readings of the structures present in the vicus and the complex composition of the excavation elements, which are sometimes not well distinguishable and classifiable. Parallel to the specific considerations on a single excavation element, exactly as for the simplified modeling, it was possible to define an overview of the excavation elements. The alignment of the different models took place on the basis of points referenced on the CAD vector data, obtaining alignment errors in the order of the centimeter, mainly caused by the lack of altimetric dimensions of the elements and the intrinsic discretization in the redesign of the elements in the CAD environment. Despite this, for the purposes of the research, it was possible to define in more detail and with greater care the spatial relationships between the excavation portions.

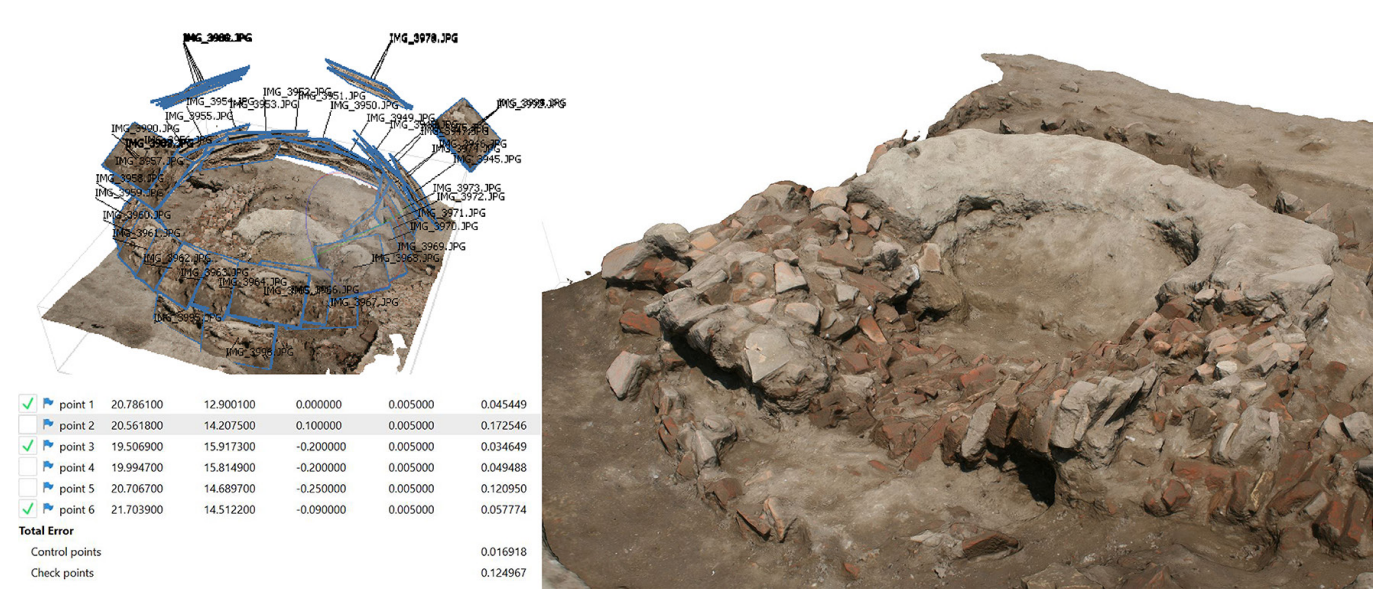

\section{Virtual scenarios for the narration of the excavation}

In the case of Bedriacum, the three-dimensional reconstruction of the excavation phases, divided over years, allowed the development of a narrative for unit, destined for a second phase of the research project. Two different experiments were carried out by first importing the simplified model of the excavations into the Unity 3D software and then the photogrammetric model in the Unreal Engine 4.0 environment. The latter, through a visual programming of the virtual system, allowed to obtain a first result for the communication of the excavation phases, confirming the graphic and perceptual influence of the photogrammetric model, compared to the simplified one.

As for programming, in both platforms it was necessary to program the user interface [7] for use through Oculus Rift and Oculus Touch systems. Subsequently, the programming also concerned the insertion of three-dimensional elements that can be interrogated which 
Fig. 8. Reconstruction of the excavation environment on the Metashape software by aligning the models in the same reference system. allow the excavation to be displayed or hidden in relation to the different years and the various actions undertaken within the archaeological site, thus creating an interactive temporal map capable of describing the history of the investigations conducted.

If on one hand the programming in Unity was easy to use, thanks also to the basic tools that the software offers, on the other the visual blueprint programming of Unreal Engine 4 depended on the knowledge bases on the interfaces and the graphic schemes of this software. Despite this, the graphic interface of UE4 has been configured as the best alternative for the development of the Virtual Reality application for Bedriacum. The result was a first application of Virtual Reality, usable entirely with Oculus systems, which allows you to move within the excavation area and to click on three-dimensional elements that indicate the year of excavation and allow you to show or hide the excavations, mainly in the area where archaeologists unearthed the urban structures of Bedriacum between 2005 and 2018 [8].
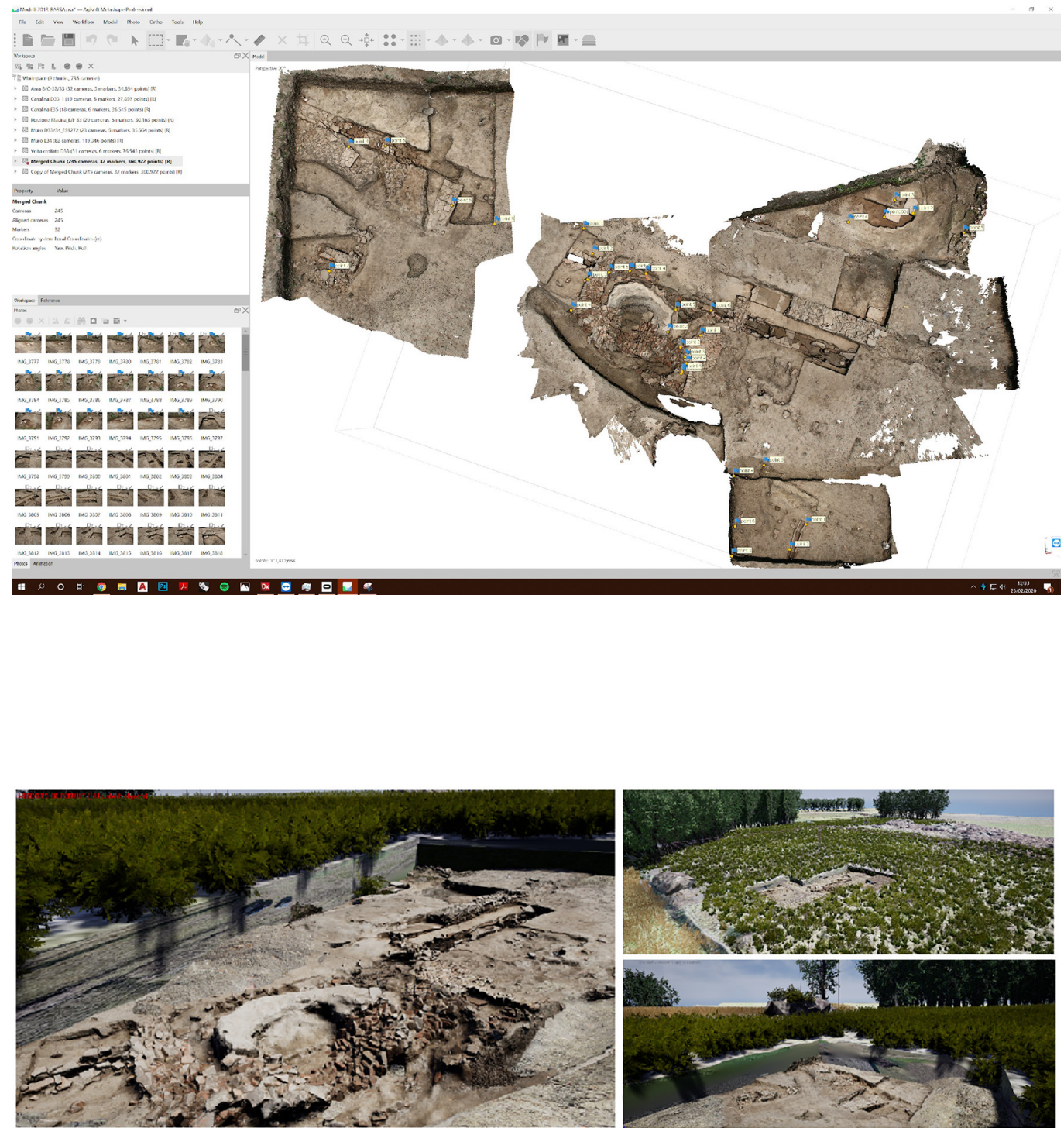
Fig. 10. Visual blueprint programming for the Bedriacum case. Graphic formatting allows more accurate control of the various programming .
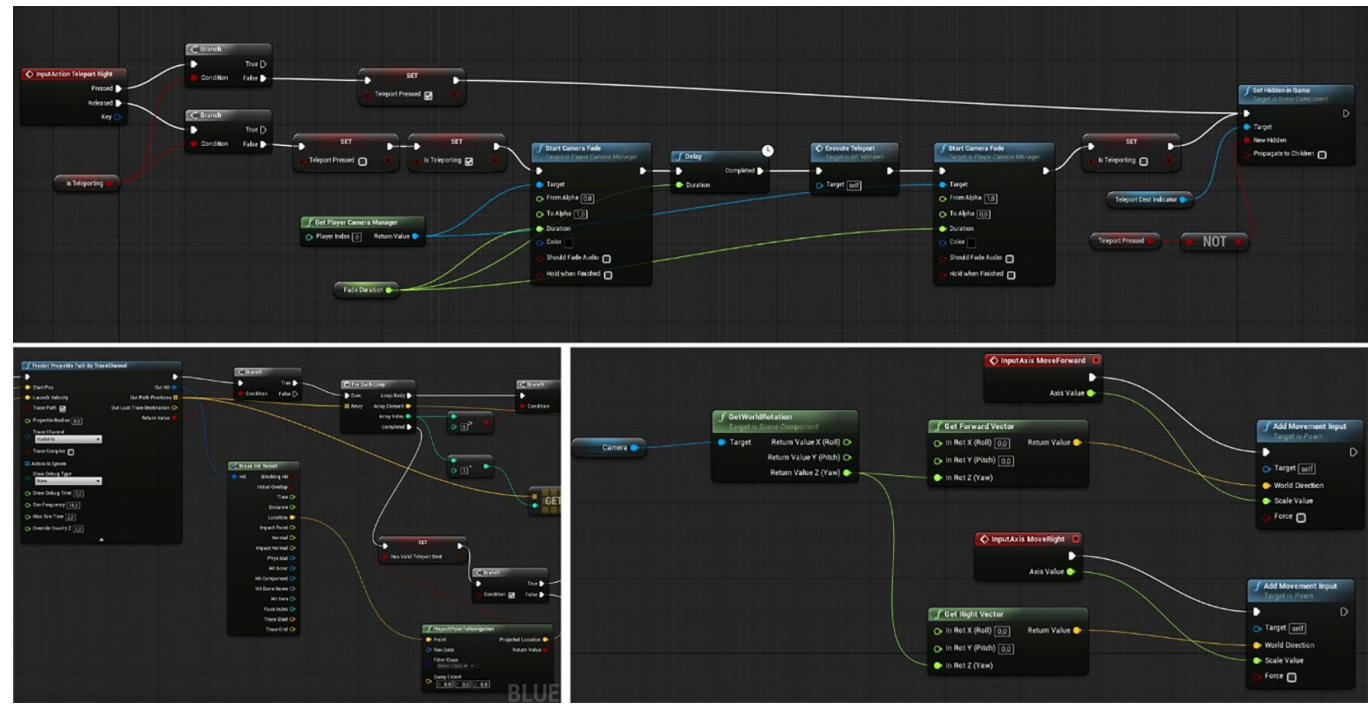

\section{Future developments}

As summarized in the previous paragraphs, three-dimensional models and representations are of fundamental importance for the purposes of communication and analysis of archaeological finds, whether they are intended as architectural structures or individual handicrafts. The use of Virtual Reality, in which the new three-dimensional systems of representation of the vicus space are inserted, will allow you to configure places and objects through the characterization of the signs and the implementation of the digital data through texts, images and sounds. Through the virtual visit of the site and of the detected and virtualized architectural asset, it will be possible to interact with a space reconstructed as a function of hypothesis and interpretation of the remains. Finally, starting from historical-constructive considerations, thanks to the virtual systems it will be possible to reconfigure the vicus settings, generating a new dissemination and communication system of the characteristics of the archaeological heritage of Bedriacum.

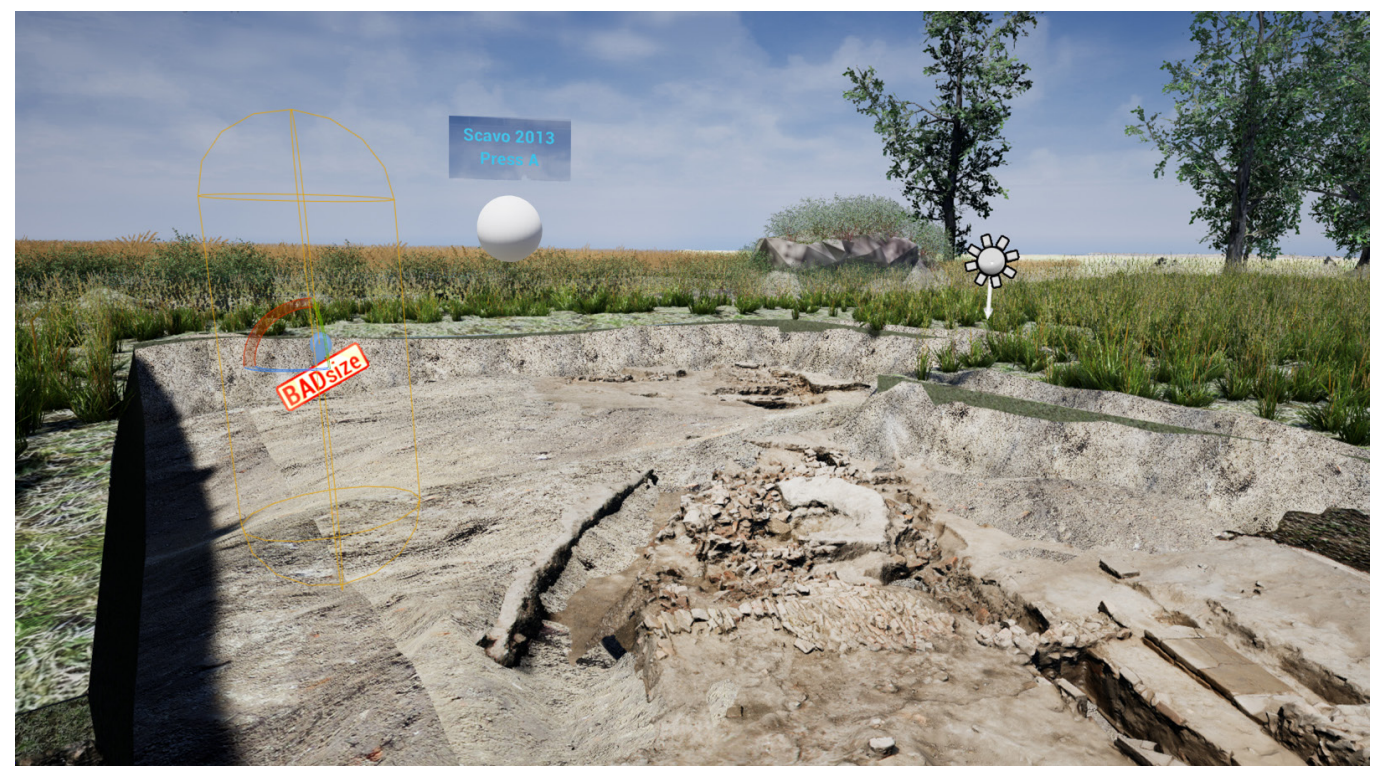




\section{Notes}

[I] In 1994 Paul Milgram and Fumio Kishino illustrated the concept of Mixed Reality in what was subsequently defined as Reality-Virtuality (RV) Continuum, that is, that scale of values that goes between the virtual and the real within the Mixed Reali. See: Milgram, Kishino 1994, pp. I321-1329.

[2] "What does the term virtual archaeology mean here? The key concept is virtual, an allusion to a model, a replica, the notion that something can act as a surrogate or replacement for an original. In other words, it refers to a description of an archaeological formation or to simulated archaeological formation. (A simulated data set will normally be shaed by the criteria used for recording an actual formation.) The problem is therefore to identify the quintessential components of the archaeological formation under investigation. All have implications for data representation and information handling": Reilly Paul (I99 I). Towards a Virtual Archaeology. In Rahtz, S. and K. Lockyear. Computer Applications and Quantitative Methods in Archaeology, In Tempus Reparatum, Oxford, pp. I 32- 139.

[3] Multiple historical sources confirmed the presence of the vicus. In particular "[...] inter Veronam Cremonamque situs est vicus, duabus iam Romanis cladibus notus infaustusque [...]" from Tacito, Historiae, II Libro.

[4]The 'Calvatone Project' started in 1986 in collaboration with the Archaeological Superintendency of Lombardy, the Institute of Archeology of the University of Milan, and the Institute of Archeology of the University of Pavia.

[5] The integrated methodology provided for various documentary actions of the excavation area through digital instrumentation Laser Scanner (FARO Focus SI 50) and mobile Laser Scanner (Kaarta Stencil) and a phase of territorial data acquisition through the use of UAV systems. From the integration of these data, a first three-dimensional mesh model of the area in which to insert the excavation elements was developed.

[6] In the specific case of Bedriacum, the documentation consists of a photographic archive of the excavation campaigns and topographical surveys of the excavation area, as well as the vector data of the structures unearthed.

[7] For the Unity 3D software, programming took place through C \# codes developed by Unity. Differently, for Unreal Engine 4.0 it was preferred to use guides and manuals for visual blueprint programming, including Kevin Mack, Robert Ruud, 2019 , Unreal Engine 4 Virtual Reality Projects: Build immersive, real-world VR applications using UE4, C ++, and Unreal Blueprints, Packt Publishing, 2019, pp 632.

[8] The documentation of the previous excavations does not allow for the development of photogrammetric models, as the photographic archive was not developed for this methodology. The integration of the 3D models of the excavations from 2001 to 2004 will take place in a second research phase in which the simplified models will be textured.

\section{References}

Asif Ali (2016). Virtual Archeology: Experiencing the Past Through Technology. In Indian Journal of Archeology, I, 3, pp. $332-337$.

Bacchetta Alberto, Grassi Maria Teresa (20I0). Dalla "Domus del Labirinto" al "Quartiere degli Artigiani”. Nuove scoperte a Calvatone Romana. In Documenta Antiquaris. Atti di Seminari di Dipartimento, pp. 27-54.

Capucci Pier Luigi (1993). Reale e Virtuale. Rappresentazioni tecnologiche, comunicazione, arte. Bologna: Clueb, p. 43.

Champion Erik (2008). Explorative Shadow Realms of Uncertain Histories. In Yehuda Kalay, Thomas Kvan, Janice Affleck (eds.). New Heritage: New Media and Cultural Heritage. London: Routledge, pp. I 85-206.

Forte Maurizio, Beltrami Roberta (2000). A proposito di Virtual Archaeology: disordini, interazioni cognitive e virtualità. In Archeologia e Calcolatori, I I. pp. 273-300.

Yu Hookk Daria (2016). "From illusion to reality: trasformation of the term "virtual archeology". In Archeological and Anthropological Sciences, 8, 4, p. 647.

Gabellone Francesco (2014). Digital Technologies and Communication: Prospects and Expectations. In Open Archaeology, pp. 102-। I8.

Gabellone Francesco (2013). II santuario di Giove Anxur a Terracina. Una ricostruzione tipologica come ausilio alla visita in situ. In Virtual Archaeology Review, 4, 9, pp. $108-115$.

Guidazzoli Antonella, Liguori Maria Chiara (200I). Realtà virtuale e Beni culturali: una relazione in evoluzione vista attraverso i progetti sviluppati presso il Cineca. In Storia e Futuro, 25, 201 I, pp. 2-26.

Guidi Gabriele, Russo Michele, Angheleddu Davide (2014). 3D survey and virtual reconstruction of archeological sites. In Digital Applications in Archeology and Cultural Heritage, I, 2, pp. 55-69.

Losier Louis Martin, Pouliot Jacynthe, Fortin Michael (2007). 3D geometrical modeling of excavation units at the archaeological site of Tell 'Acharneh (Syria). In Journal of Archaeological Science, 34, 2, pp. 272-288.

Milgram Paul, Kishino Fumio (1994). A Taxonomy of Mixed Reality Visual Displays. In IEICE Transactions on Information and Systems, E77-D, 12, pp. I321 - I329.

Parrinello Sandro, Bercigli Monica, Bursich Daniele (2017). From survey to 3d model to "videogame". The virtual reconstruction of a Roman Camp in Masada, Israel. In DisegnareCon, 10, 19.

Parrinello Sandro, Picchio Francesca (20/4). Dalla fotografia digitale al modello 3D dell'architettura storica. In DisegnareCon, La fotografia digitale, I2, pp. I- 14 . 
Parrinello Sandro, Picchio Francesca, Bercigli Monica. (2017). La 'migrazione' della realtà in scenari virtuali: Banche dati e sistemi di documentazione per la musealizzazione di ambienti complessi. In DisegnareCon, Musei virtuali dell'architettura e della città, $17,14.1-14.8$

Parrinello Sandro, Picchio Francesca (2017). Database and Complexity. Remote use of the data in the virtual space of reliable $3 \mathrm{D}$ models. In Architecture and Engineering, 2, 2, pp. 27-36.

Parrinello Sandro, Picchio Francesca, Dell'Amico Anna (2019). When the Future Is the Past. Digital Databases for the Virtualization of Museum Collection. Proceedings of the Ist International and Interdisciplinary Conference on Digital Environments for Education, Arts and Heritage, EARTH 20 I8. Bressanone, 5-6 luglio.

Ragni Maddalena (2008). La valorizzazione dei siti archeologici. Obiettivi, strategie e soluzioni. In MiBaCT. La valorizzazione dei siti archeologici. Obiettivi, strategie e soluzioni. Roma: Edizioni MP Mirabilia, p. 6-21.

Remondino Fabio (20 I I). Heritage Recording and 3D Modeling with Photogrammetry and 3D Scanning. In Remote Sensors 3, 6, pp. I 1 $04-1138$.

\section{Author}

Francesca Galasso, Università degli Studi di Pavia, francesca.galasso@unipv.it

To cite this chapter. Galasso Francesca (2020). La realtà virtuale per il racconto dell'Archeologia. Bedriacum 3D: il disegno per la narrazione di un vicus interrato/Virtual reality for the discovery of Archaeology. Bedriacum 3D: drawing for the narration of a buried vicus. In Arena A., Arena M., Brandolino R.G., Colistra D., Ginex G., Mediati D., Nucifora S., Raffa P. (a cura di). Connettere. Un disegno per annodare e tessere. Atti del $42^{\circ}$ Convegno Internazionale dei Docenti delle Discipline della Rappresentazione/Connecting. Drawing for weaving relationships. Proceedings of the 42th International Conference of Representation Disciplines Teachers. Milano: FrancoAngeli, pp. 2204-2223. 